\title{
Feeding ecology in the small neotropical amphisbaenid Amphisbaena munoai (Amphisbaenidae) in southern Brazil
}

\author{
Jorge S. Bernardo-Silva ${ }^{1}$, Eduardo M. Von-Mühlen ${ }^{2}$, Marcos Di-Bernardo ${ }^{2,3}$ \& Jochen Ketterl ${ }^{4}$ \\ 1. Pós-Graduação em Ecologia, Universidade Federal do Rio Grande do Sul, Av. Bento Gonçalves, 9500, Caixa Postal 15007, 91501-970 \\ Porto Alegre, RS, Brasil. (jorgesilva@ecologia.ufrgs.br) \\ 2. Laboratório de Herpetologia, Museu de Ciências e Tecnologia da Pontifícia Universidade Católica do Rio Grande do Sul (PUCRS), Av. \\ Ipiranga, 6681, 90619-900 Porto Alegre, Rio Grande do Sul, Brazil. \\ 3. Deceased. \\ 4. Zoologisches Institut, Universität Tübingen, Auf der Morgenstelle 28, 72076 Tübingen, Germany.
}

\begin{abstract}
We analyzed the alimentary tract of 66 specimens of Amphisbaena munoai Klappenbach, 1969 from the Serra do Sudeste, state of Rio Grande do Sul, southern Brazil. Forty specimens (60.6\%) had prey items in their gut. The diet consisted mainly of small invertebrate prey, such as termites, insect larvae and ants. The most abundant prey item was termites, found in $62.5 \%$ of the non empty stomachs. The high number of individual prey items in the majority of stomachs, the small size of the regular prey items, and the absence of gut content in specimens of $A$. munoai kept alive for about two days, indicate that this species forages very frequently. The predominance of fossorial prey items and the occasional records of nomadic ants lead us to suggest that A. munoai usually feeds underground, and occasionally forages on the surface.
\end{abstract}

KEYWORDS. Amphisbaena munoai, diet, feeding behavior, natural history, southern Brazil.

RESUMO. Ecologia alimentar da pequena anfisbaena neotropical Amphisbaena munoai (Amphisbaenidae) no sul do Brasil. Analisamos o trato digestório de 66 exemplares de Amphisbaena munoai Klappenbach, 1969 procedentes da Serra do Sudeste do Rio Grande do Sul, Brasil. Quarenta espécimes $(60,6 \%)$ possuíam presas. A dieta é composta basicamente de pequenos invertebrados, como térmitas, larvas de insetos e formigas. As presas mais abundantes foram térmitas, encontradas em 62,5\% dos estômagos não vazios. O elevado número de presas em cada indivíduo na maioria dos estômagos, o tamanho pequeno de presas regulares e a ausência de itens alimentares em espécimes de A. munoai mantidas vivas por aproximadamente dois dias, indicam que está espécie é forrageadora freqüente. A predominância de itens alimentares fossórios e o encontro ocasional de formigas nômades nos permitem sugerir que $A$. munoai usualmente se alimenta abaixo da terra e ocasionalmente na superfície.

PALAVRAS CHAVE. Amphisbaena munoai, dieta, comportamento alimentar, história natural, Serra do Sudeste.

The amphisbaenians, or worm lizards, constitutes an array of approximately 160 species of highly specialized fossorial squamates (UETZ, 2002). They have many morphological adaptations to the fossorial lifestyle, such as vestigial eyes, fused cephalic shields, a compact skull, and a trunk with a similar diameter in all its extension (GANs, 1966, 1978).

Amphisbaena munoai Klappenbach, 1969 is a small neotropical amphisbaenid, with adults attaining a maximum snout-vent length of ca. $172 \mathrm{~mm}$. It occurs from northeastern Rio Grande do Sul, Brazil, to southern and central Uruguay (GANs, 1966). Individuals of this species are easily found in open vegetation areas of the Serra do Sudeste, a moderately elevated (100-500 m) mountain region in the southwest of the State of Rio Grande do Sul.

Because they live underground, many aspects of the natural history of this and other species of amphisbaenians are difficult to observe (GANs, 1978). Consequently, the dietary information is primarily based on museum specimen studies, as in Amphisbaena darwinii Duméril \& Bibron, 1839 (CABrera \& MerLINI, 1990), A. gonavensis Gans \& Alexander, 1962 (Cusumano \& Powell, 1991), Blanus cinereus Vandelli, 1797 (LóPEZ et al., 1991), Cercolophia roberti Gans, 1964 and A. mertensii Strauch, 1881 (CRuz-Neto \& ABE, 1993), A. alba L., 1758 (Colli \& ZAMBONI, 1999), Zygaspis quadrifrons Peters, 1862 and Monopeltis anchietae Bocage, 1873
(WeBb et al., 2000), and Anops kingii Bell, 1833 (VegA, 2001) (see also Kearney, 2003 and included references). There is no information on the diet and feeding ecology of Amphisbaena munoai. In this study, we analyzed the gut content of 66 preserved specimens of A. munoai. Here we report prey types and frequency in the $\operatorname{diet}$ of $A$. munoai. Available data on specific aspects of the biology of the main prey items allow us to make inferences on the feeding behavior of the species.

\section{MATERIAL AND METHODS}

We analyzed 66 specimens of A. munoai (35 males, 30 females and 1 indefinite sex) collected between January 2000 and September 2001 in the municipalities of Dom Feliciano ( $\left.30^{\circ} 25^{\prime} \mathrm{S} ; 52^{\circ} 18^{\prime} \mathrm{W}\right)$ and Encruzilhada do Sul $\left(30^{\circ} 32^{\prime} \mathrm{S} ; 52^{\circ} 31^{\prime} \mathrm{W}\right)$, situated in the Serra do Sudeste, State of Rio Grande do Sul, southern Brazil. The main vegetation is composed by open fields with scattered shrubs and isolated, relict patches of semidecidual forests (LEITE \& KLEIN, 1990).

Most specimens were sacrificed just after collection by injection of a lethal dose of Pentobarbital. Ten individuals were kept in captivity for a maximum of 48 hours to get photographs. All specimens were deposited at the Museu de Ciências e Tecnologia (MCP), Pontifícia Universidade Católica do Rio Grande do Sul, Porto Alegre, 
Rio Grande do Sul, Brazil (Encruzilhada do Sul: MCP 11465, 12076, 12315; Dom Feliciano: MCP 11767, 11780, 1178711791, 11799-11804, 11987, 11995-11998, 12004-12008, 12019-12022, 12027-12035, 12069-12075, 12206-12213, 12374-12378, 12384, 12385, 12479, 12480, 12491).

The snout-vent length (SVL) was measured indirectly by extending a string along the belly of each individual; the string was then measured with a ruler to nearest millimeter. Each specimen was dissected by a midventral incision, from the heart to the cloaca. Laboratory dissections were made under a stereo-zoom microscope. The food items were removed from the alimentary tract (stomach and/or intestine), and deposited at the MCP collection. To make inferences about the feeding behavior, we took in consideration the development stages of the prey (larva, pupa and adult), and their respective ways of life. The minimum sample size was estimated from the cumulative diet diversity curve using Shannon-Weaver index (Shannon \& Weaver, 1949). The number of amphisbaenids with specific kind of prey was registered as occurrence, followed by the percentage of the occurrence, the number of preys found in the alimentary tract was registered as number of individuals followed for its percentage.

\section{RESULTS}

The minimum sample size was estimated in 53 individuals (Fig. 1). From 66 analyzed A. munoai, 40 $(60.6 \%)$ had a total of 323 prey items in their alimentary tract. Number of prey items in each alimentary tract varied from 1 to 58. The average of prey items in not empty tracts was 8.075. The same prey types were found in juveniles and adults, males and females. The diet was composed mainly by termites (50.9\%), followed by insect larvae (Coleoptera, Lepidoptera, Psocoptera and unidentified larvae $-24.5 \%$ ), and ants (8.4\%) (Tab. I).
Most specimens had many prey items and many prey types inside their gut. One specimen (MCP 12033) had 68 items (all termites) (Fig. 2).

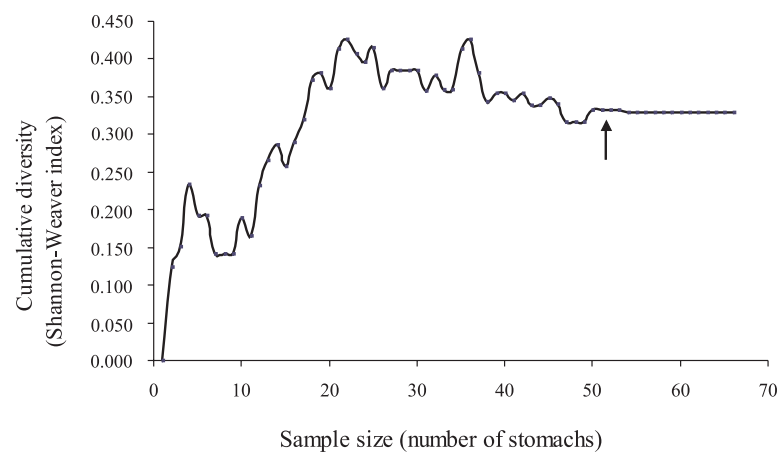

Fig. 1. Cumulative diversity for the overall sample of Amphisbaena munoai. Arrow indicates the minimum sample size (53 individuals).

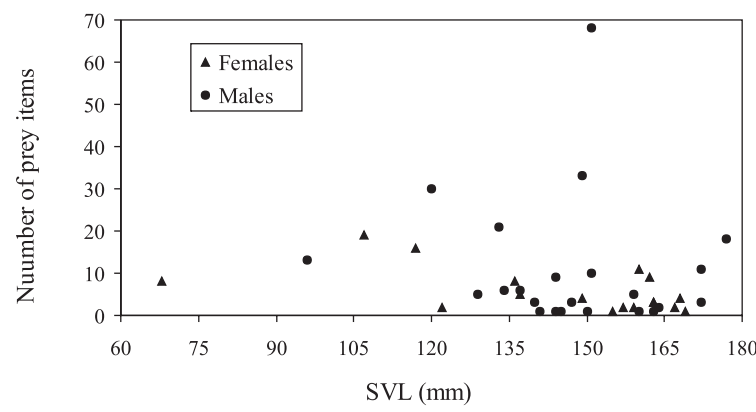

Fig. 2. Relationship between number of prey items and snout-vent length (SVL, mm) in males and females of Amphisbaena munoai in Dom Feliciano and Encruzilhada do Sul.

Table I. Prey items found in the stomachs and/or intestines of Amphisbaena munoai ( $\mathrm{N}=40)$ from Dom Feliciano and Encruzilhada do Sul, RS: O, occurrence; $\% \mathrm{O}$, percentage of occurrence; $\mathrm{N}$, number of individuals; $\% \mathrm{~N}$, percentage of number of individuals.

\begin{tabular}{|c|c|c|c|c|c|c|c|c|c|c|c|c|}
\hline \multirow[b]{2}{*}{ Prey items } & \multicolumn{4}{|c|}{ males } & \multicolumn{4}{|c|}{ females } & \multicolumn{4}{|c|}{ Total } \\
\hline & $\mathrm{O}$ & $\% \mathrm{O}$ & $\mathrm{N}$ & $\% \mathrm{~N}$ & $\mathrm{O}$ & $\% \mathrm{O}$ & $\mathrm{N}$ & $\% \mathrm{~N}$ & $\mathrm{O}$ & $\% \mathrm{O}$ & $\mathrm{N}$ & $\% \mathrm{~N}$ \\
\hline \multicolumn{13}{|l|}{ Insecta } \\
\hline \multicolumn{13}{|l|}{ Isoptera } \\
\hline Nasuti soldier & 2 & 6.45 & 11 & 4.37 & 2 & 8.00 & 10 & 10.00 & 4 & 7.14 & 21 & 6.00 \\
\hline Unidentified & 14 & 45.16 & 226 & 89.68 & 11 & 44.00 & 67 & 67.00 & 25 & 44.64 & 293 & 83.71 \\
\hline \multicolumn{13}{|l|}{ Hymenoptera } \\
\hline \multicolumn{13}{|l|}{ Formicidae } \\
\hline Neivamyrmex & 1 & 3.23 & 1 & 0.40 & 2 & 8.00 & 6 & 6.00 & 3 & 5.36 & 7 & 2.00 \\
\hline Paratrechina & 1 & 3.23 & 1 & 0.40 & & & & 0.00 & 1 & 1.79 & 1 & 0.29 \\
\hline Unidentified & 1 & 3.23 & 1 & 0.40 & & & & 0.00 & 1 & 1.79 & 1 & 0.29 \\
\hline Coleoptera (larvae) & 4 & 12.90 & 4 & 1.59 & 5 & 20.00 & 8 & 8.00 & 9 & 16.07 & 15 & 4.29 \\
\hline Lepidoptera (larvae) & 1 & 3.23 & 1 & 0.40 & 1 & 4.00 & 4 & 4.00 & 2 & 3.57 & 2 & 0.57 \\
\hline Psocoptera (larvae) & 1 & 3.23 & 1 & 0.40 & 2 & 8.00 & 2 & 2.00 & 3 & 5.36 & 1 & 0.29 \\
\hline Unidentified (larvae) & 2 & 6.45 & 2 & 0.79 & & & & 0.00 & 2 & 3.57 & 2 & 0.57 \\
\hline Unidentified & 3 & 9.68 & 3 & 1.19 & 2 & 8.00 & 3 & 3.00 & 5 & 8.93 & 6 & 1.71 \\
\hline Annelida & 1 & 3.23 & 1 & 0.40 & & & & 0.00 & 1 & 1.79 & 1 & 0.29 \\
\hline Total & 31 & & 252 & & 25 & & 100 & & 56 & & 350 & \\
\hline
\end{tabular}




\section{DISCUSSION}

The high incidence of individuals of $A$. munoai with prey items in their guts, the small size of the regular prey items, and the absence of gut content in specimens kept alive for about two days after collecting, indicate that this species feeds very frequently, as expected to amphisbaenians in general (WEBB et al., 2000). The finding of one specimen of $A$. munoai containing 68 prey items, and others containing a high number of preys, reinforce this assumption. The size of the prey was small and similar for all specimens of A. munoai (from 1 to $4 \mathrm{~mm}$ ), despite the differences of size between juveniles and adults, males and females of this species (from 68 to $172 \mathrm{~mm}$ ) (Fig 2). Within the ants, we found representatives of colonial and nomadic species.

Although conservative with regards to the size of the prey items, A. munoai seems to be generalist (sensu ScHOENER, 1971), feeding on a reasonable variety of prey types (Tab. I), without considerable differences between juveniles and adults, males and females. However, the high proportion of termites and ants may indicate that this species searches for nests of termites and nests of ants to forage, or perhaps, they live inside these nests. In fact, many specimens of A. munoai were found under rocks with a great number of termites and ants. AzEvEDORamos \& Moutinho (1994) also found A. alba and A. mitchelli Procter, 1923 living under similar circumstances. Termites and ants were found to be the main prey types of other species of amphisbaenians worldwide (e.g. Amphisbaena alba, Colli \& ZAMBONI, 1999; A. mertensii, Cruz-Neto \& Abe, 1993; Bipes biporus Cope, 1894, KEARNEY, 2003; M. anchietae and Z. quadrifrons, WEBB et al., 2000) - an indicative that this kind of prey can be preferable for these fossorial reptiles. An alternative, but not unreasonable hypothesis, is that termites and ants are among the most abundant and available prey types with adequate size, as amphisbaenians have, proportionally, the smallest mouth openings compared to other reptiles.

The predominance of fossorial prey items and the occasional record of nomadic ants, indicate that $A$. munoai feeds usually underground, and is able to forage on the surface.

Acknowledgements. We thank Arlete Ballestrin Outeiral, Lize Helena Cappellari, Rafael Lucchesi Balestrin and Maria
Cristina dos Santos Costa for collecting most of the examined specimens. Tami Mott made comments and suggestions on an earlier draft of this manuscript and provided English corrections, Márcio Borges-Martins made suggestions at final version and Raúl Maneyro provided statistical help. This work was supported by a fellowship from Conselho Nacional de Desenvolvimento Científico e Tecnológico $(\mathrm{CNPq})$, and Fundação de Amparo à Pesquisa do Rio Grande do Sul (Process \# 01504083) to JSBS. MD was partially financed by the CNPq (Process \# 300.164/00-9).

\section{REFERENCES}

Azevedo-Ramos, C. \& Moutinho, P. R. S. 1994. Amphisbaenians (Reptilia: Amphisbaenidae) in nests of Atta sexdens (Hymenoptera: Formicidae) in Estern Amazonia, Brazil. Entomological News 105(3):183-184.

Cabrera, M. R. \& Merlini, H. O. 1990. The diet of Amphisbaena darwinii heterozonata in Argentina. Herpetological Review 21(3):53.

Colli, G. R. \& Zamboni, D. S. 1999. Ecology of the Worm-Lizard Amphisbaena alba in the Cerrado of Central Brazil. Copeia (3):733-742.

Cruz-Neto, A. P. \& Abe, A. S. 1993. Diet composition of two syntopic species of neotropical amphisbaenians, Cercolophia roberti and Amphisbaena mertensii. Journal of Herpetology 27(2):239-240.

Cusumano, M. A. \& Powell, R. 1991. A note on the diet of Amphisbaena gonavensis in the Dominican Republic. Amphibia-Reptilia 12:350-352.

Gans, C. 1966. Studies on amphisbaenids (Amphisbaenia, Reptilia). 3. The small species from Southern South America commonly identified as Amphisbaena darwini. Bulletin of the American Museum of Natural History 134:187-260.

1978. The characteristics and affinities of the Amphisbaenia. Transactions of the Zoological Society of London 34:347-416.

Kearney, M. 2003. Diet in the Amphisbaenian Bipes biporus. Journal of Herpetology 37(2):404-408.

Leite, P. F. \& Klein, R. M. 1990. Vegetação. In: Fundação Instituto Brasileiro de Geografia e Estatística, Diretoria de Geociências. Geografia do Brasil, Região Sul. Rio de Janeiro, IBGE. v. 2, p.113-150.

López, P.; Martín, J. \& Salvador, A. 1991. Diet selection by the amphisbaenid Blanus cinereus. Herpetologica 47:210-218.

Schoener, T. W. 1971. Theory of feeding strategies. Annual Review of Ecology and Systematics 2:369-404.

Shannon, C. E. \& Weaver, W. 1949. The mathematical theory of communication. Urbana, Illinois University. $117 \mathrm{p}$.

Uetz, P. 2002. How many reptile species? Herpetological Review 31(1):13-15.

VEGA, L. E. 2001. Reproductive and feeding ecology of the amphisbaenian Anops kingii in east-central Argentina. Amphibia-Reptilia 22:447-454

Webb, J. K.; Shine, R.; Branch, W. R. \& Harlow, P. S. 2000. Life underground: foods and reproductive biology of two amphisbaenian species from Southern Africa. Journal of Herpetology 34(4):510-516. 